\title{
Genesis of the Yingzuihongshan Tungsten Deposit, Western Inner Mongolia Autonomous Region, North China: Constraints from In Situ Trace Elements Analyses of Scheelite
}

\author{
Guoqiang Wang ${ }^{1,2, *}$, Xiangmin $\mathrm{Li}^{1,2}$, Dongliang Zhang ${ }^{3}$, Jiyuan $\mathrm{Yu}^{1,2}$ and Yujie Liu ${ }^{4}$ \\ 1 Xi'an Center of China Geological Survey, CGS, Xi'an 710054, China; lixiangmin0728@163.com (X.L.); \\ yujiyuan111@163.com (J.Y.) \\ 2 Centre for Orogenic Belt Geology, China Geological Survey, Xi'an 710054, China \\ 3 Key Laboratory of Metallogenic Prediction of Nonferrous Metals, Ministry of Education, School of \\ Geosciences and Info-Physics, Central South University, Changsha 410083, China; dlzh04@mails.ucas.ac.cn \\ 4 Institute of Earth Environment, Chinese Academy of Sciences, Xi'an 710061, China; liuyujie@ieecas.cn \\ * Correspondence: wgq19840105@126.com or gqwangmint@gmail.com
}

\section{check for}

updates

Citation: Wang, G.; Li, X.; Zhang, D.; $\mathrm{Yu}, \mathrm{J}$; Liu, Y. Genesis of the Yingzuihongshan Tungsten Deposit, Western Inner Mongolia Autonomous Region, North China: Constraints from In Situ Trace Elements Analyses of Scheelite. Minerals 2021, 11, 510. https://doi.org/10.3390/min11050510

Academic Editors: Huan Li,

Rongqing Zhang, Jie-Hua Yang,

Jingya Cao and Maria Boni

Received: 16 March 2021

Accepted: 6 May 2021

Published: 11 May 2021

Publisher's Note: MDPI stays neutral with regard to jurisdictional claims in published maps and institutional affiliations.

Copyright: (C) 2021 by the authors. Licensee MDPI, Basel, Switzerland. This article is an open access article distributed under the terms and conditions of the Creative Commons Attribution (CC BY) license (https:/ / creativecommons.org/licenses/by/ $4.0 /)$.

\begin{abstract}
In situ analyses of trace elements and rare-earth elements (REEs) were performed by use of laser ablation-inductively coupled plasma-mass spectrometry (LA-ICP-MS) on scheelite samples from the Yingzuihongshan tungsten deposit in western Inner Mongolia Autonomous Region, China. The contents of trace elements $\mathrm{Nb}$, Ta and Mo of scheelite indicate that the ore-forming fluid is magmatic hydrotherm and is exsolved from highly fractionated granitic melt. The scheelite has high REE contents and $\sum$ REE values, and a very inhomogeneous distribution of REEs exists in different scheelite grains or even in one scheelite grain. The cathodoluminescence (CL) images of scheelite grains display well-developed zoning or fine oscillatory zoning. Development of zoning is closely related to the variable contents of REEs, and the darkness of shade of CL images are mainly determined by $\sum$ REE values, but they have no correlation with the distribution patterns of REEs. The chondrite-normalized REE distribution patterns of scheelite are classified as the middle REEs (MREEs)-enriched type, except for a strong negative Eu-anomaly, which could be a REE-flat type and or a MREEs-depleted type. Trace element composition of scheelites from the Yinzuihongshan tungsten deposit reflect that the ore-forming materials mainly came from the crust and the oreforming fluids are dominantly derived from the granitic magma in an oxidizing environment, in which very dynamic conditions of the hydrothermal system prevailed during precipitation of scheelite. On the basis of the above understanding and field geological featured, we considered that the Yingzuihongshan tungsten deposit is the quartz-vein-hosted tungsten type that is genetically associated with monzonitic granite.
\end{abstract}

Keywords: scheelite; trace elements; rare earth elements; in situ analysis; Yingzuihongshan tungsten deposit

\section{Introduction}

Rare earth elements(REEs) which belong to immobile elements have similar chemical properties and the ability to migrate as a whole during geological processes, and the composition and distribution patterns of REE are often used as a tracer to study the characteristics of ore-forming fluids that are the source of ore-forming materials and ore genesis as a tracer [1-8]; Scheelite $\left(\mathrm{CaWO}_{4}\right)$ belongs to the Ca-bearing minerals category (e.g., scheelite, fluorite and calcite), and REEs are usually incorporated into $\mathrm{Ca}^{2+}$ sites through the crystal structure of the Ca-bearing minerals in hydrothermal deposits [6,9]. In general, Ca-bearing minerals have a great capability to accommodate REEs, and therefore have a high content of REE. The scheelite is usually an ore mineral in hydrothermal tungsten deposits, and recently increasing attention has been paid to the study of REE 
characteristics of scheelite $[4,5,10-13]$. It was indicated that inhomogeneous distribution of REEs in individual grains is caused by the variation of dynamic conditions in hydrothermal systems $[5,8,14,15]$.

Traditional methods of REE analysis cannot reveal the inhomogeneous distribution of REEs, whereas in situ analysis can reveal the inhomogeneous distribution of REEs not only in different grains but also in different parts of the same grain. In addition, in situ analysis (by use of LA-ICP-MS) can ensure the facticity of experiment data, and therefore has significant advantages compared with traditional methods [8,16]. An increasing number of studies have been focused on the REE distribution of the scheelite, garnet and fluorite by use of LA-ICP-MS [5,8,14,17-23].

The medium-scale Yingzuihongshan tungsten deposit is located in the EjinaBanner, AlashanLeague, Inner Mongolia, and is about $45 \mathrm{~km}$ to the north of Dongqiyi Mountain (Figure 1a). It was first discovered by the Qilianshan Geological Brigade of Gansu Bureau of Geology and Mineral Resources in 1950. Recently, the Pantuoshan, Guoqing, and Wangxushan tungsten deposits were discovered in the Pantuoshan-Yingzuihongshan granitoid belt. Previous studies have summarized the geological characters of the PantuoshanYingzuihongshan granitoid belt and the relevant tungsten deposits, together with geochronological and geochemical work [24-29].However, the previous REE geochemical studies of country rocks are limited, and the mineralogical and geochemical features of scheelite within the tungsten deposits have not been studied. The intentions of this contribution are to study the characteristics of trace element and REEs of scheelite in the Yingzuihongshan tungsten deposit, which will lead to a better understanding on the source of ore-forming fluid, the source of ore-forming materials and the mineralization process of the tungsten deposit.

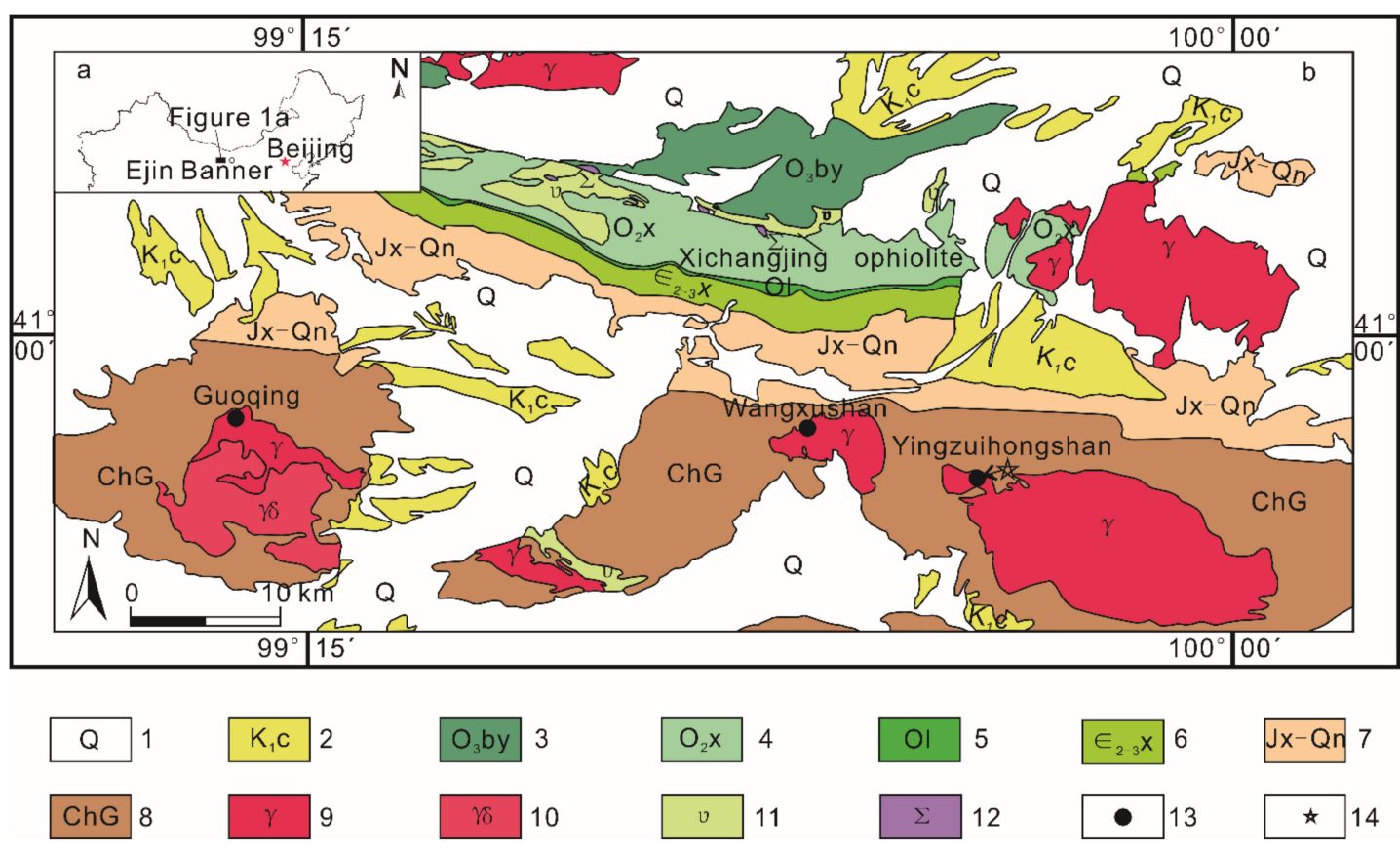

Figure 1. (a) Location of the study area. (b) simplified geological map of the tungsten-bearing granitoid belt and adjacent areas [26]. 1Quaternary; 2 Cretaceous Chijinbao Formation: conglomerate, sandstone, siltstone and mudstone; 3Upper Ordovician Baiyunshan Formation: sandstone, conglomerate and limestone, intercalated with intermediate-acidic volcanic rocks and jasperite; 4Middle Ordovician Xilinkebo Formation: intermediate-basic volcanic rocks, intercalated with carbonate and minor clastic rocks; 5Ordovician Luoyachushan Formation: clastic rocks, intercalated with argillaceous limestone and minor chert; 6Cambrian Xishuangyingshan Formation: carbonate, chert and siliceous slate; 7Mesoproterozoic to Neoproterozoic: marble, dolomitic limestone, dolomite and siliceous bands intercalated with limestone; 8Paleoproterozoic Gudongjing Group: phylite, slate, quartzite, and sercite-quartz schist, intercalated with marble; 9granite; 10granodiorite; 11gabbro; 12plagioclase-pyroxene peridotite and serpentinized peridotite; 13tungsten deposit; 14Yingzuizhongshan tungsten deposit. 


\section{Geological Background and Mineralization Characteristics}

The Yingzuihongshan tungsten deposit is located in the Beishan orogen, which belongs to the southern margin of $\mathrm{CAOB}$ (the Central Asia Orogenic Belt), and in the east section of the Pantuoshan-Gudonging tectonic lift extending in the E-W direction due to compressive stress, which is closely adjacent to the north side of the Hongliuhe-Niujuanzi-Xichangjing ophiolitic tectonic melange (Figure 1b).Large amounts of granitoids were emplaced in the Beishan region, and many ore deposits were formed in the granitoids, varying from Caledonian to Hercynianore deposits [30-33]. The Pantuoshan, Guoqing, Wangxushan and Yingzuihongshan tungsten deposits occur in the same granitoid belt [26,27].

Adjacent to the Yingzuihongshan tungsten deposit, the widely distributed Paleoproterozoic Gudongjing Group is composed of phylite, slate, quartzite and sericite-quartz schist, intercalated with minor marble. With an outcrop area of about $150 \mathrm{~km}^{2}$, the Yingzuihongshan granitic pluton which intruded into the Gudongjing Group (Figure 1b) is composed mainly of biotite granite and monzonitic granite. The granitic rocks of the Yingzuihongshan tungsten deposit are S-type and I-type, and were formed in the Late Devonian [25]. Tungsten mineralization occurs mainly within a series of quartz veins in the northern inner contact zone of the granitic body, and the shape of the orebody is controlled by the NE-striking fault or a small part of the NW-striking fault, and these faults are also important conducting and host structures of tungsten deposits [25].

The mining area of the Yingzuihongshan tungsten deposit is composed of east and west blocks. The eastern ore block is discussed on this paper. The length of the eastern ore block is $185 \mathrm{~m}$ and the width is $70 \mathrm{~m}$, and this block contains dozens of scheelite-quartz veins (Figure 2).The ore body of W18 is the biggest one of the eastern ore block, and its length is $102 \mathrm{~m}$, the average thickness is $2.8 \mathrm{~m}$, the thickness of the ore body decreases gradually from the northwest to the southeast region, the maximum inclined depth is less than $70 \mathrm{~m}$ and the attitude is close to upright [34] (Figure 2).

Quartz-vein tungsten deposits, which are associated with granite, are the most important tungsten deposit type in the Beishan area, including for the Yingzuihongshan tungsten deposit. Ore minerals are mainly wolframite and scheelite, followed by chalcopyrite, pyrite, galena, molybdenite and arsenopyrite. Gangue minerals are dominated by quartz, followed by tourmaline, potassium feldspar, sericite, beryl, fluorite and calcite. There are three mineralization stages: the first and main stage is taxitic-spotted wolframite; the second stage is massive wolframite; the third stage is fine veined wolframiteand and scheelite. Ore textures are mainly hypidiomorphic-idiomorphic granular. Ore structures are mostly taxitic-spotted, veinlet and disseminated [34].

The major ore types of the Yingzuihongshan tungsten deposit include scheelitewolframite-quartz vein and tourmaline-wolframite-quartz vein, and the minor ore type is scheelite-wolframite-arsenopyrite-quartz vein. The wall rocks are intensively altered, and the predominant alteration types are silicification and greisenization, with minor tourmalinization, sericitization and pyritization. The silicification is closely related to the tungsten mineralization, while the intensive silicification belt usually occurs in both sides of the tungsten bearing quartz veins [26]. 


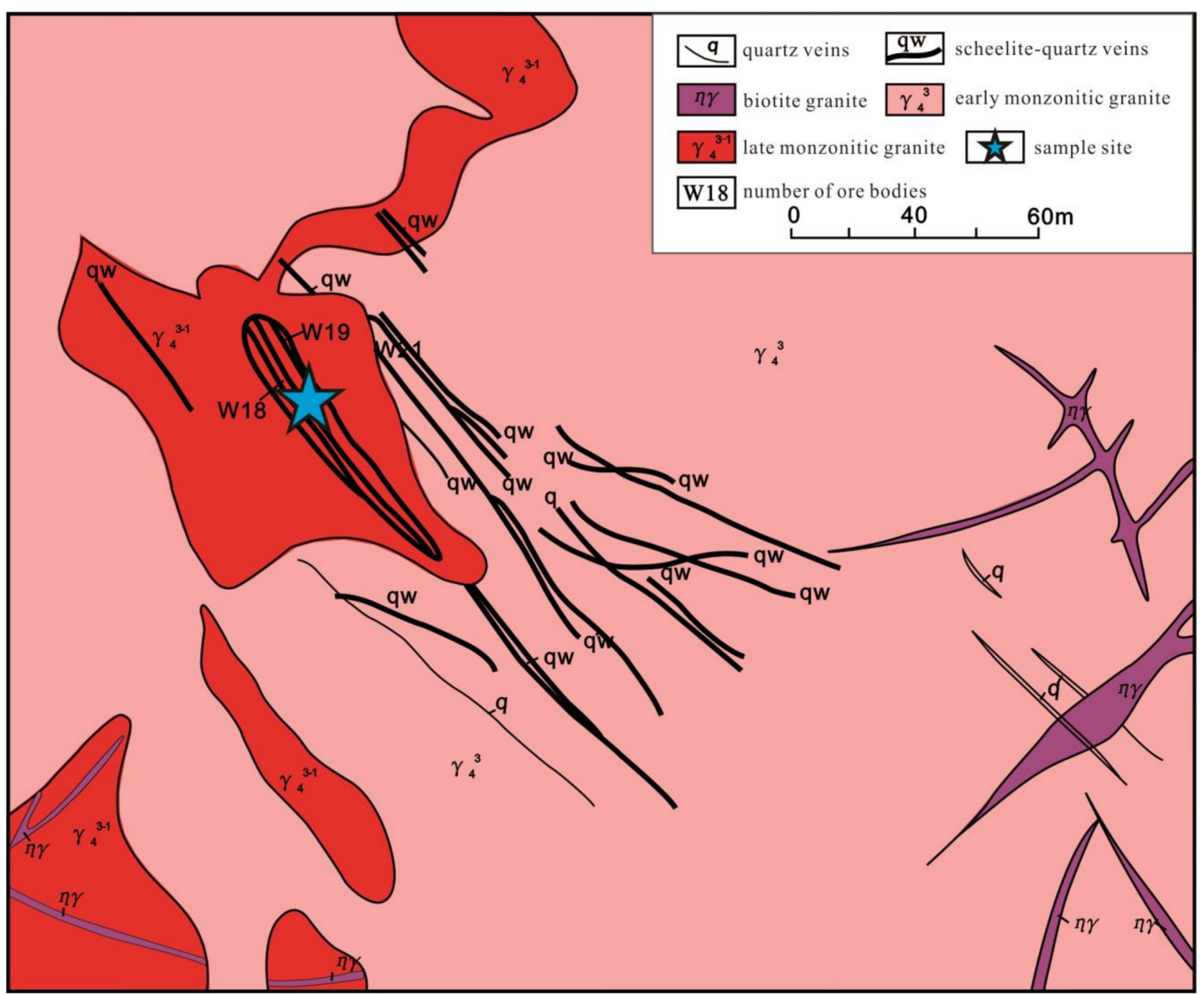

Figure 2. Simplified geological map of the eastern ore block of the Yingzuihongshan tungsten deposit [34].

\section{Sample Descriptions and Analytical Methods}

Previous studies for in situ analysis were performed by use of LA-ICP-MS on a single crystal or thin section of scheelite. Because it is difficult to collect single scheelite crystal from lode tungsten deposits, and in situ analysis on thin sections that are not the direct analytical object may affect the experimental results, in this study the trace element in situ analysis was carried out by use of LA-ICP-MS on individual scheelite grains, which were mounted in epoxy.

Four samples were collected from a scheelite-quartz vein of the western district of the eastern ore block of the Yingzuihongshan tungsten deposit. Scheelite is white colored, with oil luster, and the crystal habit is mostly in a euhedral tetragonal bipyramid form. The samples were preprocessed through crushing and grinding, and then by the use of conventional density techniques, scheelite grains(from 40 to 60 meshes) were separated from the scheelite-quartz vein. The scheelite grains with a purity of above $99 \%$ were selected by means of a fluorescent lamp, and were mounted in epoxy mounts, which were then polished to section the crystals in half for in situ analysis. The trace element in situ analyses were performed by laser ablation inductively coupled plasma-mass spectrometry(LAICP-MS (Agilen, Yokogawa, Japan)), and the content of $\mathrm{CaO}$ was measured on the laser ablation pits by electron microprobe(EMP (JEOL, Tokyo, Japan)), with the content of calcium as an internal standard. Analytical work by use of LA-ICP-MS, and EMP, CL imaging (Figure 3a-d) and analysis of REEs of host rock were all carried out at the Key 
Laboratory for the Study of Focused Magmatism and Giant Ore Deposits, Ministry of Land and Resources, Xi'an Center of Geological Survey. Samples were analyzed by use of an Agilent 7700 $\times$ ICP-MS (Agilen, Yokogawa, Japan) equipped with a ComPex102 Excimer 193-nm ArF laser and MicroLasGeoLas $200 \mathrm{M}$ optics. The laser ablation of a single pit was found to be $44 \mu \mathrm{m}$ wide and 20-40 $\mu \mathrm{m}$ deep. NIST610 and NIST612 were used as external standards by using analytical procedures similar to those described by [35]. The content of $\mathrm{CaO}$ of scheelite was analyzed by use of a JXA-8230 electron microprobe (JEOL, Tokyo, Japan)operated at $20 \mathrm{kV}$ and $10 \mathrm{nA}$, with an electron beam $(5 \mu \mathrm{m}$ in diameter). X-Series II inductively coupled plasma-mass spectrometry(analytical error below $5 \%$ ) was used for the analysis of REEs of the host rock.
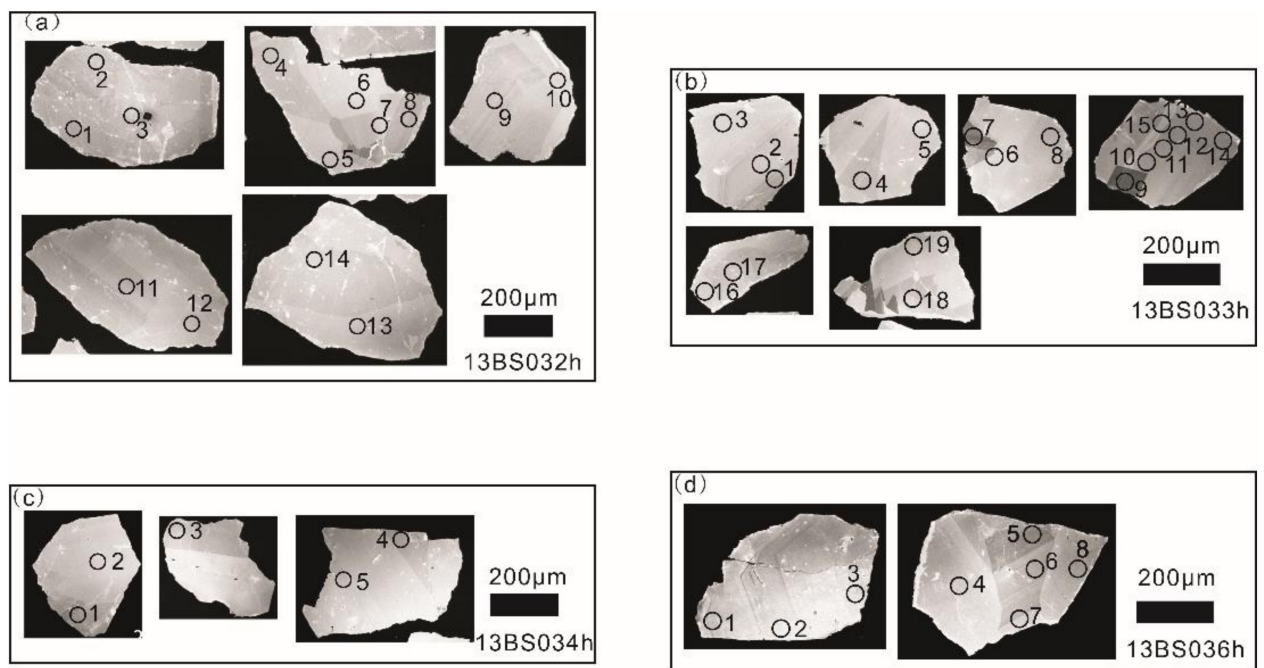

Figure 3. CL images of scheelite grains of four samples $(\mathbf{a}-\mathbf{d})$ collected from the Yingzuihongshan tungsten deposit. The small circles with numbers represent laser ablation pits.

\section{Analytical Results of Trace Elements in Scheelite}

The analyzed scheelite grains contain 43.21-130.65 ppm of Sr, 0.68-99.83 ppm of Ta and 1.99-9.66 ppm of Mo, and have high $\mathrm{Nb}$ contents ranging from $45.55 \mathrm{ppm}$ to $2667.10 \mathrm{ppm}$ (Table 1).

Compared with other mineral deposits whose trace element characteristics of scheelite in the quartz vein were well used in the study of ore genesis (Table 2), the Sr contents of scheelite from the Yingzuihongshan tungsten deposit are much lower than those of scheelite from the Yangjingou scheelite deposit in Jilin Province, Daping gold deposit in Yunnan Province and Archaean greenstone belt gold deposit in Western Australia. In contrast, the $\mathrm{Mo}, \mathrm{Nb}$ and $\mathrm{Ta}$ contents of scheelite from the Yingzuihongshan tungsten deposit are much higher than those of scheelite from the Yangingou scheelite deposit in Jilin Province and Daping gold deposit in Yunnan Province, and are different from those of scheelite from the Archaean greenstone belt gold deposit in Western Australia. In general, $\mathrm{Mo}, \mathrm{Nb}$, Ta and $\mathrm{W}$ are mainly enriched at the pneumato hydrothermal stage, and are the products of magmatic crystallization differentiation in the late period; these elements have similar geochemical behavior and mainly exist in scheelite or wolframitein the form of isomorphic admixture, especially Mo when it is enriched in scheelite [36]. Scheelite from the Yingzuihongshan tungsten deposit has high contents of $\mathrm{Mo}, \mathrm{Nb}$ and $\mathrm{Ta}$ (Table 1), which suggest that the ore-forming fluid may be derived predominantly from the magmatic hydrotherm. Moreover, the content of Mo is higher than that of primitive mantle, but is comparable to the continental crust (the Mo contents of primitive mantle and continental crust are $0.059 \mathrm{ppm}$ and $1 \mathrm{ppm}$, respectively; [37]). This suggests that the ore-forming materials of the Yingzuihongshan tungsten deposit may be related to the continental crust. 
Table 1. Trace element contents $\left(\times 10^{-6}\right)$ of scheelite grains from the Yingzuihongshan tungsten deposit.

\begin{tabular}{|c|c|c|c|c|c|c|c|c|c|c|c|}
\hline Sample & $\mathrm{Ba}$ & $\mathrm{Sr}$ & $\mathrm{Nb}$ & Ta & Mo & Sample & Ba & $\mathrm{Sr}$ & $\mathrm{Nb}$ & Ta & Mo \\
\hline 13BS032h-1 & 0.333 & 87.06 & 740.63 & 18.93 & 3.91 & 13BS033h-10 & 0.0207 & 48.73 & 595.78 & 16.06 & 3.36 \\
\hline 13BS032h-2 & 0.226 & 67.3 & 825.91 & 45.81 & 8.15 & 13BS033h-11 & 0.0164 & 44.21 & 462.96 & 9.16 & 3.29 \\
\hline 13BS032h-3 & 0.389 & 57.35 & 647.74 & 33.57 & 9.66 & 13BS033h-12 & 0.0055 & 44.79 & 490.39 & 10.55 & 2.82 \\
\hline 13BS032h-4 & 0.0087 & 54.48 & 839.54 & 27.24 & 3.41 & 13BS033h-13 & 0.0112 & 47.02 & 455.37 & 9.85 & 2.71 \\
\hline 13BS032h-5 & 0.0377 & 53.94 & 644.67 & 18.31 & 3.27 & 13BS033h-14 & 1.289 & 49.36 & 446.43 & 9.93 & 4.69 \\
\hline 13BS032h-6 & 0.0053 & 45.96 & 556.55 & 13.78 & 2.77 & 13BS033h-15 & 0.0206 & 44.17 & 478.23 & 9.76 & 3.32 \\
\hline 13BS032h-7 & 0.0414 & 48.46 & 811.12 & 25.41 & 2.37 & 13BS033h-16 & 0.0148 & 51.61 & 689.52 & 37.47 & 5.49 \\
\hline 13BS032h-8 & 0.0364 & 72.54 & 1325.15 & 44.25 & 1.99 & 13BS033h-17 & 2.32 & 55.74 & 978.04 & 60.31 & 4.41 \\
\hline 13BS032h-9 & 0.0428 & 54.99 & 804.19 & 53.11 & 5.62 & 13BS033h-18 & 0.228 & 50.91 & 661.37 & 13.16 & 3.51 \\
\hline 13BS032h-10 & 0.0078 & 48.56 & 710.7 & 38.28 & 3.86 & 13BS033h-19 & 0.181 & 49.16 & 484.02 & 9.21 & 3.76 \\
\hline 13BS032h-11 & 0.0132 & 50.5 & 823.79 & 35.48 & 3.88 & 13BS034h-1 & 0.0446 & 55.01 & 874.33 & 48.18 & 4.26 \\
\hline 13BS032h-12 & 0.0321 & 46.46 & 642.77 & 19.24 & 3.75 & 13BS034h-2 & 0.049 & 50.58 & 636.85 & 25.52 & 4.33 \\
\hline 13BS032h-13 & 0.064 & 43.21 & 473.66 & 10.64 & 2.83 & 13BS034h-3 & 0.116 & 130.65 & 549.93 & 10.99 & 2.99 \\
\hline 13BS032h-14 & 0.312 & 55.43 & 774.83 & 21.02 & 3.31 & 13BS034h-4 & 0.208 & 51.38 & 755.18 & 22.04 & 3.16 \\
\hline 13BS033h-1 & 0.11 & 60.54 & 444.23 & 9 & 2.97 & 13BS034h-5 & 0.0029 & 48.68 & 449.33 & 8.91 & 2.4 \\
\hline 13BS033h-2 & 0.0026 & 54.2 & 271.68 & 5.06 & 2.23 & 13BS036h-1 & 0.084 & 71.63 & 125.64 & 1.66 & 2.46 \\
\hline 13BS033h-3 & 0.0028 & 50.95 & 55.55 & 0.864 & 2.87 & 13BS036h-2 & 0.0111 & 44.78 & 103.62 & 1.266 & 2.43 \\
\hline 13BS033h-4 & 0.283 & 53.96 & 605.07 & 14.66 & 3.83 & 13BS036h-3 & 0.295 & 47.04 & 85.58 & 1.009 & 2.08 \\
\hline 13BS033h-5 & 0.0273 & 54.57 & 464.74 & 12.04 & 3.52 & 13BS036h-4 & 0.0155 & 44.75 & 630.57 & 38.49 & 9.48 \\
\hline 13BS033h-6 & 0.122 & 51.33 & 162.14 & 3.13 & 3.49 & 13BS036h-5 & 0.0156 & 50.65 & 925.56 & 38.3 & 6.34 \\
\hline 13BS033h-7 & 0.138 & 52.93 & 488.74 & 9.42 & 2.34 & 13BS036h-6 & 0.127 & 44.7 & 813.17 & 20.63 & 7.8 \\
\hline 13BS033h-8 & 0.0075 & 59.21 & 45.55 & 0.68 & 2.77 & 13BS036h-7 & 0.0449 & 46.58 & 913.87 & 49.18 & 6.27 \\
\hline 13BS033h-9 & 0.045 & 63.6 & 2667.1 & 99.83 & 3.07 & 13BS036h-8 & 0.0415 & 49.37 & 627.52 & 34.8 & 4.66 \\
\hline
\end{tabular}

Table 2. Trace element contents $\left(\times 10^{-6}\right)$ of scheelite from different mineral deposits.

\begin{tabular}{ccccc}
\hline Element & $\begin{array}{c}\text { Daping Gold Deposit } \\
\text { in Yunnan Province, } \\
\text { China }\end{array}$ & $\begin{array}{c}\text { Yangjingou Scheelite } \\
\text { Deposit in Jilin } \\
\text { Province, China }\end{array}$ & $\begin{array}{c}\text { Archaean Greenstone } \\
\text { Belt Gold Deposit in } \\
\text { Western Australia }\end{array}$ & $\begin{array}{c}\text { Yingzuihongshan } \\
\text { Tungsten Deposit }\end{array}$ \\
\hline $\mathrm{Mo}$ & $0.47-1.39$ & $0.06-0.15$ & LOD-3.71 & $1.97-9.66$ \\
$\mathrm{Sr}$ & $1127-1610$ & $168-238$ & $341-4280$ & $43.21-130.65$ \\
$\mathrm{Nb}$ & $0.01-0.02$ & $0.08-0.32$ & $0.06-3.18$ & $45.55-2667.10$ \\
$\mathrm{Ta}$ & $0.10-0.11$ & $0.03-0.04$ & $85.3-1142$ & $0.68-99.83$ \\
data sources & {$[38]$} & {$[12]$} & {$[14]$} & This paper \\
\hline
\end{tabular}

LODlimit of detection calculated from repeated measurements of NIST610.

REE analytical results are listed in Table 3, and the REE distribution patterns of scheelite from the Yingzuihongshan tungsten deposit are presented in Figure 3. The REE geochemical characteristic is described as follows:

(1) The analyzed scheelite grains have higher REE contents, with $\sum$ REE values ranging from 715.86 to $3947.95 \mathrm{ppm}$ and $\sum R E E+Y$ values ranging from 1031.05 to $5638.83 \mathrm{ppm}$. The $\sum \mathrm{REE}+\mathrm{Y}$ values of scheelite from the Yingzuihongshan tungsten deposit are obviously higher than those of scheelite samples which come from the Yangjingou scheelite deposit in Jilin Province (178.7-276.6 ppm; [12]), Daping gold deposit in Yunnan Province (17602004 ppm; [38]), Woxi Au-Sb-W deposit in western Hunan Province (40.5-123.6 ppm; [4]), Zhazixi W-Sb deposit in western Hunan Province (11.3-136.9 ppm; [5]), Xianghuapu tungsten deposit in southern Hunan Province (0.73-61.13 ppm; [8]), Xuebaoding W-Sn-Be deposit in Sichuan Province (369-1302 ppm; [10]), Archaean greenstone belt gold deposit in Western Australia (288 to $4376.91 \times 10^{-6}$; [14]) and gold deposits in the KalgoorlieNorseman region in Western Australia (17.01-2746 ppm; [18]).

(2) Ghaderi et al. [18] subdivided the scheelite from the Archaean greenstone belt gold deposit in Western Australia into two distinct types according to the chondrite-normalized REE distribution patterns: middle REEs (MREEs)-enriched type (humped-shaped; type I) and MREEs-depleted type (flat; type II), which have been widely accepted $[5,10,13,14,18,38]$. 
Samples 13BS032h and 13BS034h from the Yingzuihongshan tungsten deposit show convex upward REE distribution patterns (Figure 4) that are nearly the same as those of MREEs-enriched type (type I), except for a strong negative Eu-anomaly. However, samples 13BS033h and 13BS036h have two or more kinds of REE distribution patterns. For example, points 3, 6, 7 and 8 of sample 13BS033h show MREEs-depleted patterns, and points 16 and 17 have the same REE patterns as those of samples 13BS032h and 13BS034h, whereas the other points of sample 13BS033h show MREEs-depleted patterns with a flat shape (type II) except for a strong negative Eu-anomaly. Points 1, 2 and 3 of sample 13BS036h show flat REE distribution patterns with negative (points 1 and 2) or weak positive (point 3) Eu-anomalies, and point 6 shows MREE-impoverished patterns, whereas the other points of sample 13BS036h show the same patterns as those of samples 13BS032h and 13BS034h.
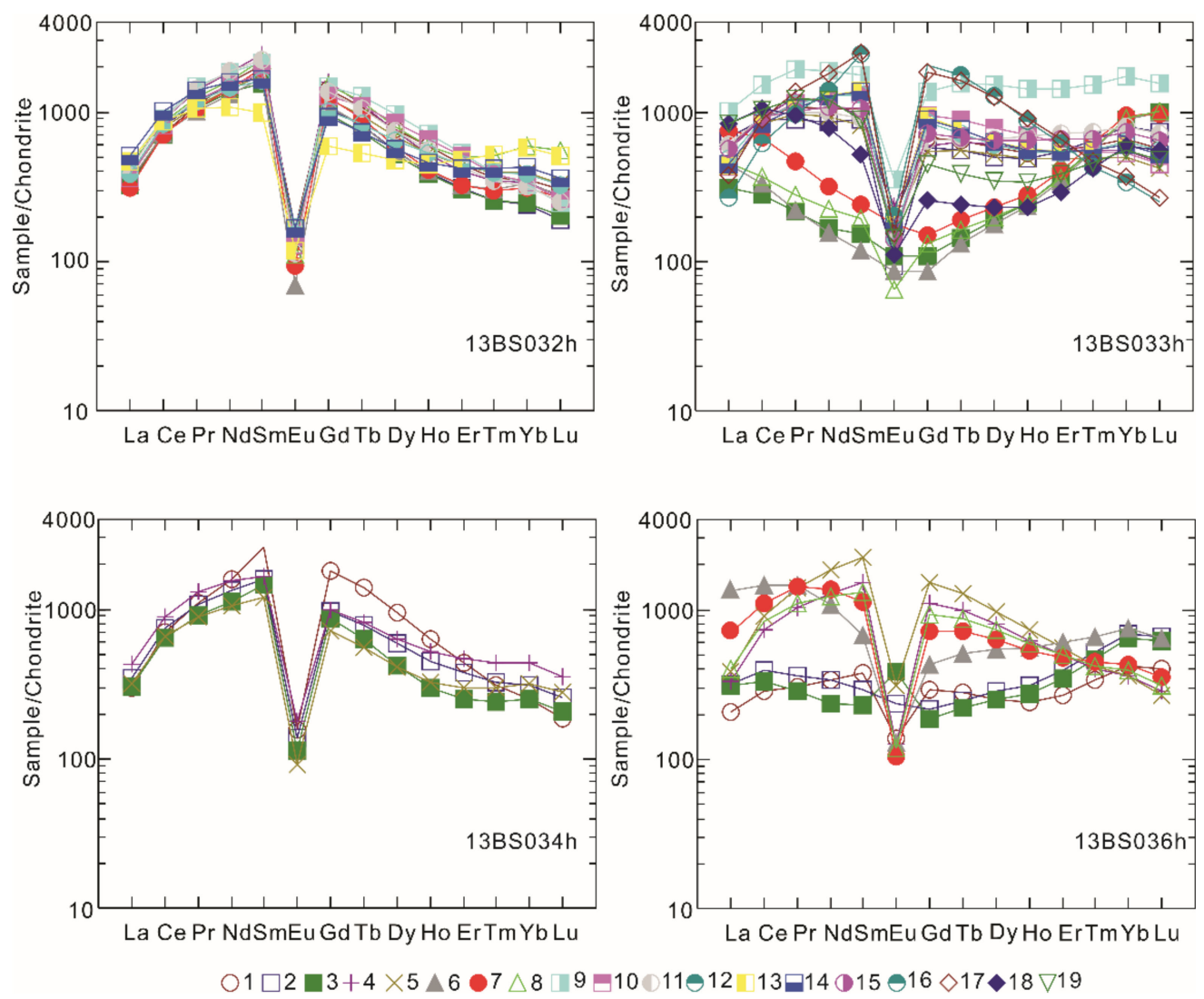

Figure 4. Chondrite-normalized [39] REE distribution patterns of scheelite grains from the Yingzuihongshan tungsten deposit.

The REE distribution patterns of scheelite from the Yingzuihongshan are very inhomogeneous and can change abruptly among different scheelite grains from the same sample, or even in different zones of the same scheelite grain (e.g., points 1, 2 and 3 of sample 13BS033; point 4, 5, 6, 7 and 8 of sample 13BS036). Although this study supports the viewpoint of REE inhomogeneity proposed in previous studies $[5,14,16,18]$, the REE distribution patterns of scheelite from the Yingzuihongshan tungsten deposit are complex, especially with obviously negative Eu-anomalies (except for point 3of sample13BS036h) that are different from those of typical type I and type II REE distribution patterns. In addition, points 3, 6, 7 and 8 of sample 13BS033h show MREEs-depleted patterns which were only reported from the Zhazixi W-Sb deposit in western Hunan Province by [5]. 


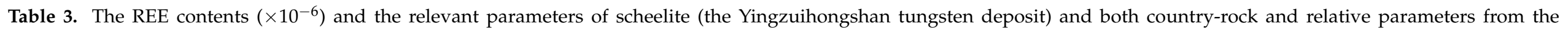
Yingzuihongshan tungsten deposit.

\begin{tabular}{|c|c|c|c|c|c|c|c|c|c|c|c|c|c|c|c|c|c|c|}
\hline Sample & $\mathbf{L a}$ & $\mathrm{Ce}$ & Pr & $\mathrm{Nd}$ & Sm & Eu & Gd & $\mathrm{Tb}$ & Dy & Ho & Er & $\mathrm{Tm}$ & $\mathbf{Y b}$ & $\mathbf{L u}$ & $\mathbf{Y}$ & $\sum \mathrm{REE}$ & $\delta \mathrm{Eu}$ & $\delta \mathrm{Ce}$ \\
\hline \multicolumn{19}{|c|}{ scheelite } \\
\hline 13BS032h-1 & 79.5 & 442.36 & 104.86 & 745.34 & 314.19 & 9.68 & 292.71 & 40.46 & 196.36 & 33.68 & 73.98 & 9.19 & 60.11 & 7.67 & 653.9 & 2410.09 & 0.10 & 1.00 \\
\hline 13BS032h-2 & 87.49 & 491.59 & 111.59 & 707.41 & 267.37 & 8.26 & 216.28 & 30.2 & 141.66 & 22.48 & 51.18 & 6.59 & 40.87 & 4.84 & 624.9 & 2187.81 & 0.10 & 1.04 \\
\hline 13BS032h-4 & 100.4 & 548.2 & 131.27 & 866.98 & 374.83 & 8.75 & 322.72 & 42.39 & 190.61 & 29.5 & 66.46 & 8.8 & 57.69 & 6.94 & 615.8 & 2755.51 & 0.08 & 0.99 \\
\hline 13BS032h-5 & 87.95 & 481.55 & 104.73 & 666.64 & 271.02 & 7.54 & 251.42 & 35.18 & 174.71 & 30.15 & 72.13 & 9.98 & 67.44 & 8.47 & 666.6 & 2268.91 & 0.09 & 1.07 \\
\hline 13BS032h-6 & 81.65 & 437.24 & 95.58 & 614.02 & 258.35 & 3.98 & 227.39 & 30.2 & 137.98 & 22.75 & 54.05 & 7.78 & 56 & 7.16 & 486.5 & 2034.13 & 0.05 & 1.06 \\
\hline 13BS032h-7 & 74.41 & 433.17 & 101.24 & 670.07 & 301.04 & 5.46 & 258.88 & 34.3 & 151.02 & 23.16 & 53.31 & 7.56 & 52.86 & 6.81 & 520.6 & 2173.29 & 0.06 & 1.03 \\
\hline 13BS032h-9 & 107.5 & 561.18 & 142.49 & 868.78 & 326.62 & 8.84 & 304.24 & 47.38 & 245.57 & 40.53 & 87.4 & 9.96 & 55.36 & 6.23 & 760.4 & 2812.10 & 0.08 & 0.94 \\
\hline 13BS032h-10 & 85.39 & 499.79 & 113.87 & 714.1 & 277.4 & 7.45 & 263.66 & 40.91 & 216.82 & 37.06 & 83.42 & 9.89 & 57.52 & 6.61 & 777.7 & 2413.89 & 0.08 & 1.05 \\
\hline 13BS032h-11 & 98.32 & 539.6 & 135.48 & 871.55 & 342.78 & 6.52 & 281.02 & 39.57 & 192.05 & 31.57 & 71.31 & 8.84 & 54 & 6.4 & 698.7 & 2679.01 & 0.06 & 0.96 \\
\hline 13BS032h-12 & 92.12 & 505.76 & 111.95 & 676.22 & 245.83 & 9.96 & 209.98 & 31.19 & 163.32 & 29.83 & 73.96 & 10.04 & 65.63 & 8.18 & 711.9 & 2233.97 & 0.13 & 1.05 \\
\hline 13BS032h-13 & 110.2 & 537.29 & 100.1 & 499.18 & 152.24 & 6.88 & 122.32 & 19.89 & 120.8 & 25.27 & 78.55 & 13.25 & 97.96 & 12.85 & 666 & 1896.77 & 0.15 & 1.16 \\
\hline 13BS032h-14 & 119.8 & 616.2 & 132.63 & 739.76 & 250.98 & 9.66 & 189.1 & 27.33 & 142.45 & 25.89 & 69.85 & 10.77 & 73.27 & 9.15 & 626.3 & 2416.83 & 0.13 & 1.06 \\
\hline 13BS033h-1 & 137 & 562.24 & 102.76 & 496.14 & 162.83 & 11.41 & 138.19 & 24.02 & 145.99 & 30.39 & 91.59 & 15.14 & 112.35 & 14.47 & 648.9 & 2044.47 & 0.23 & 1.11 \\
\hline 13BS033h-2 & 159.3 & 540.17 & 84.78 & 401.13 & 136.35 & 5.43 & 119.47 & 20.56 & 126.21 & 27.61 & 90.07 & 16.38 & 134.85 & 18.71 & 539.9 & 1880.98 & 0.13 & 1.13 \\
\hline 13BS033h-3 & 74.41 & 170.57 & 20.6 & 78.18 & 23.41 & 6.35 & 22.3 & 5.41 & 48.26 & 13.91 & 60.73 & 14.56 & 151.88 & 25.29 & 315.2 & 715.86 & 0.84 & 1.05 \\
\hline 13BS033h-5 & 102.1 & 506.36 & 91.81 & 437.72 & 126.15 & 9.58 & 110.62 & 20.53 & 131.45 & 27.47 & 80.5 & 12.54 & 85.38 & 10.75 & 758.6 & 1752.91 & 0.24 & 1.18 \\
\hline 13BS033h-6 & 105.5 & 204.05 & 21 & 72.33 & 18.01 & 4.94 & 17.79 & 4.95 & 45.61 & 13.33 & 57.84 & 14.27 & 150.99 & 24.95 & 333.8 & 755.58 & 0.83 & 1.00 \\
\hline 13BS033h-7 & 175.9 & 410.07 & 44.18 & 149.85 & 36.48 & 10.38 & 30.79 & 7.07 & 58.77 & 15.97 & 66.86 & 15.89 & 162.88 & 24.47 & 462.5 & 1209.60 & 0.92 & 1.11 \\
\hline 13BS033h-8 & 107.7 & 227.39 & 26.49 & 105.5 & 29.55 & 3.77 & 27.16 & 6.07 & 50.28 & 14.02 & 60.37 & 14.59 & 155.63 & 25.77 & 358.9 & 854.30 & 0.40 & 1.01 \\
\hline 13BS033h-9 & 241.2 & 932.07 & 183.65 & 880.51 & 268.54 & 20.58 & 282.33 & 57.78 & 388.42 & 81.25 & 236.41 & 39 & 296.99 & 39.23 & 1691 & 3947.95 & 0.23 & 1.03 \\
\hline 13BS033h-10 & 102.4 & 542.42 & 110.24 & 601.48 & 199.39 & 10.94 & 193.04 & 33.05 & 199.79 & 39.51 & 102.96 & 13.88 & 90.56 & 11.28 & 856.7 & 2250.97 & 0.17 & 1.11 \\
\hline 13BS033h-11 & 144 & 569.22 & 94.26 & 465.83 & 139.2 & 8.23 & 133.77 & 24.49 & 167.17 & 38.86 & 118.7 & 18.78 & 136.58 & 18.13 & 777.6 & 2077.17 & 0.18 & 1.16 \\
\hline 13BS033h-12 & 116.3 & 549.96 & 107.41 & 596.83 & 198.94 & 8.36 & 173.8 & 27.12 & 155.13 & 30.71 & 88.4 & 14.22 & 107.14 & 14.14 & 709.3 & 2188.49 & 0.13 & 1.11 \\
\hline
\end{tabular}


Table 3. Cont

\begin{tabular}{|c|c|c|c|c|c|c|c|c|c|c|c|c|c|c|c|c|c|c|}
\hline Sample & La & $\mathrm{Ce}$ & $\operatorname{Pr}$ & $\mathrm{Nd}$ & Sm & $\mathrm{Eu}$ & Gd & $\mathrm{Tb}$ & Dy & Ho & Er & Tm & $\mathrm{Yb}$ & $\mathbf{L u}$ & $\mathbf{Y}$ & $\sum \mathrm{REE}$ & $\delta \mathrm{Eu}$ & $\delta \mathrm{Ce}$ \\
\hline 13BS033h-13 & 102.9 & 505.17 & 101.35 & 595.34 & 214.87 & 10.84 & 191.52 & 28.84 & 161.01 & 31.75 & 89.82 & 14.1 & 101.97 & 13.26 & 681.2 & 2162.69 & 0.16 & 1.10 \\
\hline 13BS033h-14 & 105.1 & 515.33 & 101.07 & 592.18 & 209.06 & 10.64 & 184.15 & 28.69 & 161.36 & 31.67 & 90.28 & 14.15 & 102.29 & 13.29 & 681.4 & 2159.26 & 0.16 & 1.12 \\
\hline 13BS033h-15 & 134.1 & 562.72 & 96.39 & 506.78 & 160.14 & 8.17 & 146.17 & 25.37 & 162.57 & 36.41 & 107.96 & 16.66 & 123.91 & 16.3 & 822.7 & 2103.60 & 0.16 & 1.16 \\
\hline 13BS033h-17 & 88.43 & 539.5 & 130.73 & 846.89 & 380.38 & 8.82 & 380.98 & 60.8 & 315.31 & 51.65 & 108.37 & 11.82 & 63.26 & 6.78 & 947.9 & 2993.72 & 0.07 & 1.01 \\
\hline 13BS033h-18 & 198.7 & 639.2 & 90.17 & 366.78 & 78.98 & 6.47 & 52.28 & 8.92 & 58.29 & 13.12 & 48.73 & 10.74 & 100.05 & 14.07 & 372.8 & 1686.52 & 0.29 & 1.17 \\
\hline 13BS033h-19 & 199.1 & 627.63 & 117.19 & 559.69 & 134.81 & 8.41 & 92.04 & 14.32 & 87.97 & 19.35 & 63.92 & 11.74 & 94.23 & 12.2 & 392.6 & 2042.62 & 0.22 & 0.99 \\
\hline 13BS034h-1 & 70.8 & 427.79 & 105.54 & 742.18 & 394.75 & 9.17 & 374.66 & 52.24 & 240.15 & 35.81 & 72.71 & 8.01 & 42.93 & 4.68 & 766.3 & 2581.42 & 0.07 & 0.99 \\
\hline 13BS034h-3 & 71.77 & 395.18 & 86.45 & 529.04 & 221.06 & 6.59 & 177.99 & 23.56 & 106.68 & 16.81 & 41.43 & 6.11 & 42.66 & 5.29 & 353.1 & 1730.62 & 0.10 & 1.06 \\
\hline 13BS034h-4 & 101 & 546.9 & 124.62 & 726.28 & 255.85 & 10.24 & 202.81 & 30.22 & 161.13 & 29.58 & 77.76 & 11.11 & 74.19 & 9.05 & 724.4 & 2360.75 & 0.13 & 1.03 \\
\hline 13BS034h-5 & 74.74 & 400.25 & 84.17 & 489.16 & 184.06 & 5.29 & 147.96 & 20.61 & 103.5 & 18.27 & 49.3 & 7.6 & 54.35 & 7.05 & 413.1 & 1646.31 & 0.09 & 1.09 \\
\hline 13BS036h-1 & 49.04 & 174.54 & 29.12 & 157.03 & 58.2 & 7.91 & 60.04 & 10.37 & 63.76 & 13.64 & 44.5 & 8.55 & 71.5 & 10.15 & 390.5 & 758.35 & 0.41 & 1.11 \\
\hline 13BS036h-2 & 75.66 & 240.53 & 34.51 & 157.91 & 44.99 & 13.6 & 44.75 & 9.25 & 71.73 & 17.71 & 65 & 13.21 & 116.2 & 16.76 & 563.6 & 921.81 & 0.92 & 1.15 \\
\hline 13BS036h-3 & 73.05 & 203.95 & 27.01 & 109.59 & 34.89 & 22.11 & 37.8 & 8.32 & 63.8 & 15.32 & 57.49 & 11.98 & 109.05 & 15.56 & 496 & 789.92 & 1.85 & 1.12 \\
\hline 13BS036h-4 & 78.79 & 449.6 & 98.41 & 601.16 & 233.67 & 7.3 & 228.63 & 37.11 & 203.45 & 35.09 & 82.35 & 10.24 & 61.41 & 7.28 & 884.3 & 2134.49 & 0.10 & 1.07 \\
\hline 13BS036h-5 & 90.82 & 554.05 & 131.69 & 861.14 & 342.18 & 17.96 & 310.79 & 47.43 & 247.92 & 41.43 & 91.2 & 10.62 & 60.85 & 6.81 & 888.9 & 2814.89 & 0.17 & 1.02 \\
\hline 13BS036h-6 & 315.6 & 881.85 & 136.93 & 500.45 & 103.42 & 7.54 & 87.82 & 18.91 & 137.76 & 31.08 & 99.09 & 16.96 & 126.77 & 16.32 & 872.3 & 2480.45 & 0.24 & 1.04 \\
\hline 13BS036h-8 & 95.2 & 509.07 & 103.88 & 578.5 & 199.2 & 6.93 & 191.51 & 32.76 & 187.76 & 33.68 & 81.82 & 10.67 & 66.7 & 7.88 & 884.3 & 2105.56 & 0.11 & 1.11 \\
\hline \multicolumn{19}{|c|}{ monzonitic granite } \\
\hline 13BS037h & 26.8 & 60.9 & 7.66 & 30.4 & 7.72 & 0.45 & 6.73 & 1.08 & 6.41 & 1.3 & 3.69 & 0.57 & 3.62 & 0.53 & 31.7 & 157.86 & 0.19 & 1.03 \\
\hline 13BS038h & 40.5 & 81.9 & 10.1 & 41.8 & 10.9 & 0.81 & 9.92 & 1.6 & 10.1 & 2.11 & 5.88 & 0.91 & 5.77 & 0.82 & 55 & 223.12 & 0.23 & 0.97 \\
\hline $13 \mathrm{BS} 039 \mathrm{~h}$ & 36.1 & 71.9 & 8.75 & 35.2 & 9.25 & 0.76 & 8.88 & 1.48 & 9.42 & 1.96 & 5.54 & 0.86 & 5.37 & 0.76 & 52.4 & 196.23 & 0.25 & 0.96 \\
\hline 13BS040h & 41.7 & 88.1 & 10.8 & 43.6 & 12.3 & 0.65 & 11.7 & 1.92 & 11.5 & 2.28 & 6.16 & 0.91 & 5.55 & 0.78 & 59.6 & 237.95 & 0.16 & 0.99 \\
\hline 13BS041h & 23 & 49.5 & 6.32 & 27.5 & 7.66 & 0.42 & 7.61 & 1.32 & 8.11 & 1.6 & 4.58 & 0.67 & 4.16 & 0.6 & 40.4 & 143.05 & 0.17 & 0.99 \\
\hline
\end{tabular}




\section{Discussions}

\subsection{Ore-Forming Materials and Parent-Fluid Source of the Yingzuihongshan Tungsten Deposit}

The REE composition and distribution pattern of hydrothermal Ca-bearing minerals have been widely used to trace the source of ore-forming materials and fluids and to study the genesis of deposits [1-3]. The ionic radius of $\mathrm{Eu}^{2+}$ is similar to that of $\mathrm{Ca}^{2+}$ of scheelite, and is larger than that of $\mathrm{Eu}^{3+}$. Scheelite has a great capability to accommodate $\mathrm{Eu}^{2+}$, and both $\mathrm{Eu}^{2+}$ and $\mathrm{Eu}^{3+}$ can exist in the crystal structure of scheelite [2,4]. The REE distribution patterns of scheelite from most of the studied mineral deposits in the world show a positive Eu-anomaly $[4,5,8,12-14,18,38]$, and the others show a negative Eu-anomaly $[10,40,41]$.

Scheelite from deposits hosted in felsic to intermediate rocks commonly has a negative $\mathrm{Eu}$ anomaly [42]; the scheelite of magmatic hydrothermal system is generally considered to inherit the REE distribution patterns of the parent granite (e.g., negative Eu anomalies), indicating a genetic link to the granite $[43,44]$. In this study, Ce anomalies of scheelite grains are not very obvious $(\delta \mathrm{Ce}=0.94-1.18$; Table 3$)$, whereas nearly all analyses of scheelite grains (except for point 3 of sample 13BS036h; $\delta \mathrm{Eu}=1.85$ ) from the Yingzuihongshan tungsten deposit show strong negative Eu-anomalies $(\delta \mathrm{Eu}=0.05-0.92$, Table 3) (Figure 4). The REE distribution patterns of five samples collected from the Yingzuihongshan monzonitic granite (Figure 5) are also characterized by an obvious negative Eu-anomaly $(\delta \mathrm{Eu}=0.16-0.25$, Table 3$)$. The scheelite grains have almost no obvious Ce-anomaly $(\delta \mathrm{Ce}=0.94-1.18$, Table 3 ), which is consistent with the Ce-anomaly $(\delta \mathrm{Ce}=0.96-1.03$, Table 3$)$ of the ore-bearing monzonitic granite. The characteristic of the Ce-anomaly also implies that the monzonitic granite is the main source of mineralization to a certain extent. The REE geochemical characteristic of both the monzonitic granite and scheelite, combined with the close spatial relationship between the monzonitic granite (host rock) and tungsten deposit, suggests that they have a genetic relationship. The characteristics of trace elements of scheelite also indicate a curst-origin of the mineral in this deposit. Moreover, the $\mathrm{Ca}^{2+}$ source is also crucial for the forming of the scheelite. Due to the monzonitic granite that intruded into the Gudongjing Group in the Yingzuihongshan mining area, we inferred that the $\mathrm{Ca}^{2+}$ of scheelite is largely provided by the marble in the Gudongjing Group. Furthermore, the Yingzuihongshan tungsten deposit is related to the S-type granite [26]. The evidence listed above shows that the ore-forming materials mainly come from the crust source.

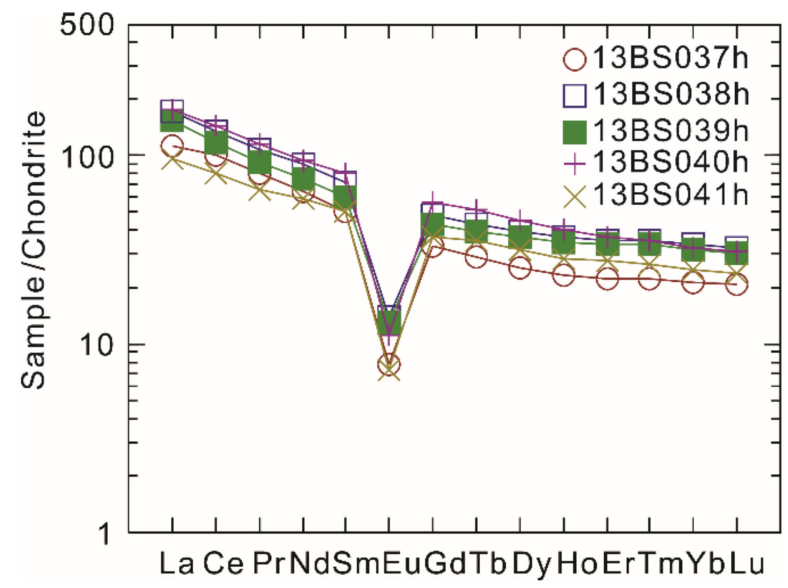

Figure 5. Chondrite-normalized [39] REE distribution patterns of monzonitic granite adjacent to the Yingzuihongshan tungsten deposit.

Mo content in scheelite could be affected by the redox conditions of ore-forming fluids; when the oxygen fugacity is high, Mo occurs as $\mathrm{Mo}^{6+}$ to replaces $\mathrm{W}^{6+}$ in scheelite, while a high Mo content in scheelite generally reflects an oxidizing environment $[18,23]$. The scheelite of the Yingzuihoignshan tungsten deposit has a high Mo concentration that possibly indicates an oxidizing environment. In the vein type tungsten deposit, ore-forming 
materials and fluid have a relatively single magmatic origin [45], and the ore-forming fluids of quartz-vein-hosted tungsten deposits are generally derived from magmatic evolution [45-47]. Therefore, evolved granitic magmas in an oxidizing environment are considered as the main ore-forming fluid source of the Yingzuihongshan tungsten deposit, though more detailed identification of the ore-forming fluid source requires further isotopic evidence to be obtained.

\subsection{Inhomogeneous Distribution of REEs in Scheelite}

The backscattered electron (BSE) images of scheelite grains do not show any zonation and growth gaps, but zonal structures of some scheelite grains are obvious in their CL images (Figure 3a-d). Zoning of scheelite grains in CL images is closely related to the REE contents and their distribution patterns $[14,48]$. LA-ICP-MS analyses in this study indicate that dark gray zones in CL images have higher REE contents than the light gray zones (Figure $3 a-d$ ). The $\sum R E E+Y$ values of scheelite from the Yingzuihongshan tungsten deposit are higher than those of scheelite grains from the worldwide mineral deposits reported in the references. The internal zones or oscillatory zoning in the CL images of scheelite grains from other mineral deposits (e.g., the Zhazixi W-Sb deposit, [5]; Xianghuapu tungsten deposit, [8]; Daping gold deposit, [49])do not exist or are not as clear as those of scheelite from the Yingzuihongshan tungsten deposit. This suggests that the depth of shade of CL images is mainly determined by the $\sum$ REE values. Because the CL images of scheelite grains from the Archaean greenstone belt gold deposit in Western Australia [14] have been digitally enhanced, they cannot be compared with those of scheelite grains from the Yingzuihongshan tungsten deposit.

Some scheelite grains from the Yingzuihongshan tungsten deposit are characterized by a fine oscillatory zoning, with zone widths smaller than $25 \mu \mathrm{m}$. Variation of $\sum$ REE values reveals that the definition of zoning is closely related to higher REE contents. The depth of shade of CL images is mainly determined by the $\sum$ REE values, but has no correlation with the REE distribution patterns of the same grain, which suggests that REEs are inhomogeneously distributed in scheelite from the Yinzuihongshan tungsten deposit.

The REE zoning in various minerals has been reported by many authors, for example in zircon [50], calcite [51], fluorite [52] and scheelite [53]. Inhomogeneous distribution of trace elements in natural minerals may arise from various primary and secondary processes. Sector zoning formed during crystallization dynamic processes is a primary feature causing the inhomogeneous distribution of trace elements, and secondary processes often involve fluids which infiltrate along the rim of a mineral or within fractures [54]. The analytical points of inhomogeneous distribution of REEs in this study are not along the rim of scheelite or within fractures, which suggests that the factor of involved fluid is evaded. Therefore, this implies that the internal zoning and REE inhomogeneity of scheelite grains from the Yingzuihongshan tungsten deposit may be determined by the crystallization dynamic processes.

In addition, cautions have been taken while conducting traditional REE analyses of bulk samples of REE-rich scheelites, as this only yields a mixed average value, and this value may provide false geochemical information [5,14]. In this study, the in situ LA-ICP MS methods for scheelite grains confirmed the fact that the obvious REE inhomogeneity among the scheelite from the Yinzuihongshan tungsten deposit found through in situ analysis methods for scheelite ensures that credible geochemical information can be obtained.

\subsection{Ore-Forming Hydrothermal System of the Yingzuihongshan Tungsten Deposit}

Because the ionic radii of $\mathrm{REE}^{3+}$ are similar to that of $\mathrm{Ca}^{2+}$, scheelite is a Ca-bearing mineral and usually contains abundant REE in the form of isomorphism [6,14]. REEbearing minerals and REE-rich inclusions do not exist in the scheelite of Yingzuihongshan, as evidenced under the electron microscope; therefore, isomorphism is the main existing form for REE from Yingzuihongshan scheelite. The REE contents and their distribution patterns of scheelite from the Yingzuihongshan tungsten deposit change abruptly among 
different scheelite grains and even in different parts of the same grain. The feature of change was interpreted by [14], as that very dynamic conditions prevailed during precipitation of scheelite.

In this study, all samples were collected from a scheelite-quartz vein of the Yingzuihongshan tungsten deposit, where scheelite coexists with quartz. This is because quartz does not have a selectivity effect on REEs, and the REE patterns of the solution cannot change during the precipitation of quartz. Consequently, the early precipitation of MREEsrich mineral may be scheelite itself, because the crystal structure of scheelite is conductive to the enrichment of MREEs $[4,14,18,22]$. In the natural hydrothermal system, REE concentrations are usually low in hydrothermal fluids [55-57]. Precipitation of scheelite results in a strong REE fraction, and the REE patterns of scheelite are highly sensitive to the dynamics of the hydrothermal system $[14,58]$. Therefore, MREEs in the early ore-forming fluid are incorporated into scheelite and the precipitation of MREEs-rich scheelite significantly alters the composition of the hydrothermal fluid and produce a MREEs-depleted fluid, which results in the subsequent formation of REE-flat even MREE-impoverish scheelite. In conclusion, we consider that this likely reveals a complete dynamic evolution process with very dynamic conditions occurring in the Yingzuihongshan tungsten deposit.

\subsection{Ore Genesis of the Yingzuihongshan Tungsten Deposit}

The elements $\mathrm{Nb}$, Ta, REEs and Mo are generally enriched in the high-temperature stage of magmatic crytallization differentiation, while in the vein type tungsten deposit, ore-forming material and fluid have a relatively single magmatic origin [45]. Scheelite from the Yingzuihongshan tungsten deposit has high contents of $\mathrm{Mo}, \mathrm{Nb}$ and Ta; Eu-anomalies of scheelite are similar to the ore-bearing monzonitic granite; the $\delta \mathrm{Ce}$ value of scheelite is basically consistent to the $\delta \mathrm{Ce}$ value of the ore-bearing monzonitic granite; the monzonitic granite of Yingzuihongshan tungsten deposit is considered to be the product of crust remelting and belong to the S-type granite [26]; this evidence shows that the crust-derived characteristics of ore-forming material and the ore-forming fluid were likely derived from the magmatic origin in the Yingzuihongshan tungsten deposit. Furthermore, the main output form is a scheelite-quartz vein of the Yingzuihongshan tungsten deposit, where scheelite coexists with quartz. In summary, we consider that Yingzuihongshan tungsten is a quartz-vein-hosted tungsten deposit with tungsten that is related to monzonitic granite.

\section{Conclusions}

(1) The high $\mathrm{Nb}$, Ta and Mo contents of scheelite from the Yingzuihongshan tungsten deposit suggest that the ore-forming materials mainly came from the crust, while the ore-forming fluid is pneumato-hydrothermal in an oxidizing environment and is derived from the granitic magma.

(2) Scheelite from the Yingzuihongshan tungsten deposit has much higher REE contents and $\sum R E E$ values compared with those of scheelite from other mineral deposits in the world. Most of them have well-developed internal zoning that is closely related to the high REE contents. The inhomogeneous distribution of REEs exists in different scheelite grains, or even in different parts of the same grain. The chondrite-normalized REE distribution patterns of scheelite from the Yingzuihongshan tungsten deposit can be classified into the MREEs-enriched type, REE-flat type and MREEs-depleted type, probably revealing a complete dynamic evolution process with very dynamic conditions that reflect this scheelite formation.

(3) The Yingzuihongshan tungsten deposit is the quartz-vein-hosted tungsten type associated with monzonitic granite.

Author Contributions: Conceptualization, G.W.; methodology, X.L. and D.Z.; article writing and figure drawing, G.W.; writing-review and editing, G.W. and Y.L.; sample collection, G.W. and J.Y. All authors have read and agreed to the published version of the manuscript. 
Funding: This study was financially supported by the National Natural Science Foundation for Youth of China (G.W., grant numbers 41703038), the Natural Science Foundation of Shaanxi Province (G.W., grant numbers 2015JM4144) and the China Geological Survey Project (to G.W.: DD20190812).

Data Availability Statement: Data sharing is not applicable.

Acknowledgments: We sincerely thank the three anonymous reviewers who have provided significant comments and suggestions that have greatly improved this paper. We appreciate the valuable comments from Li Huan, Chris Brown, and Heather $\mathrm{Wu}$, respectively.

Conflicts of Interest: The authors declare no conflict of interest.

\section{References}

1. Bau, M.; Romer, R.L.; Lüders, V.; Dulski, P. Tracing element sources of hydrothermal mineral deposits: REE and Y distribution and $\mathrm{Sr}-\mathrm{Nd}-\mathrm{Pb}$ isotopes in fluorite from MVT deposits in the Pennine Orefield, England. Miner. Depos. 2003, 38, 992-1008. [CrossRef]

2. Brugger, J.; Etschmann, B.; Pownceby, M.; Liu, W.; Grundler, P.; Brewe, D. Oxidation state of europium in scheelite: Tracking fluid-rock interaction in gold deposits. Chem. Geol. 2008, 257, 26-33. [CrossRef]

3. Peng, J.T.; Hu, R.Z.; Qi, L.; Zhao, J.H.; Fu, Y.Z. REE distribution pattern for the hydrothermal calcites from the Xikuangshan antimony deposit and its constraining factors. Geol. Rev. 2004, 50, 25-32. (In Chinese)

4. $\quad$ Peng, J.T.; Hu, R.Z.; Zhao, J.H.; Fu, Y.Z.; Yuan, S.D. Rare earth element (REE) geochemistry for scheelite from the Woxi Au-Sb-W deposit western Hunan. Geochimica 2005, 34, 115-122. (In Chinese)

5. Peng, J.T.; Zhang, D.L.; Hu, R.Z.; Wu, M.J.; Liu, X.M.; Qi, L.; Yu, Y.G. Inhomogeneous distribution of rare earth elements (REEs) in scheelite from the Zhazixi W-Sb deposit, western Hunan and its geological implications. Geol. Rev. 2010, 56, 810-819. (In Chinese)

6. Schönenberger, J.; Köhler, J.; Markl, G. REE systematics of fluorides, calcite and siderite in peralkaline plutonic rocks from the Gardar Province, South Greenland. Chem. Geol. 2008, 247, 16-35. [CrossRef]

7. Song, S.W.; Mao, J.W.; Xie, G.Q.; Jian, W.; Chen, G.H.; Rao, J.F.; Ouyang, Y.P. Petrogenesis of scheelite-bearing albitite as an indicator for the formation of a world-class scheelite skarn deposit: A case study of the Zhuxi Tungsten deposit. Econ. Geol. 2021, 116, 91-121. [CrossRef]

8. Zhang, D.L.; Peng, J.T.; Fu, Y.Z.; Peng, G.X. Rare-earth element geochemistry in Ca-bearing minerals from the Xianghuapu tungsten deposit, Hunan province, China. Acta Petrol. Sin. 2012, 28, 65-74. (In Chinese)

9. Dostal, J.; Kontak, D.J.; Chatterjee, A.K. Trace element geochemistry of scheelite and rutile from metaturbidite-hosted quartz vein gold deposits, Meguma Terrane, Nova Scotia, Canada: Genetic implications. Miner. Petrol. 2009, 97, 95-109. [CrossRef]

10. Liu, Y.; Deng, J.; Li, C.F.; Shi, G.H.; Zhen, A.L. REE composition in scheelite and scheelite Sm-Nd dating for the Xuebaoding W-Sn-Be deposit in Sichuan. Chin. Sci. Bull. 2007, 52, 2543-2550. (In Chinese) [CrossRef]

11. Liu, B.; Li, H.; Wu, Q.-H.; Evans, N.J.; Cao, J.-Y.; Jiang, J.-B.; Wu, J.-H. Fluid evolution of Triassic and Jurassic W mineralization in the Xitian ore field, South China: Constraints from scheelite geochemistry and microthermometry. Lithos 2019, 330-331, 1-15. [CrossRef]

12. Ren, Y.S.; Zhao, H.L.; Lei, E.; Wang, H.; Ju, N.; Wu, C.Z. Trace element and rare earth element geochemistry of the scheelite and ore genesis of the Yangjingou large scheelite deposit in Yanbian area, northeastern China. Acta Petrol. Sin. 2010, 26, 3720-3726. (In Chinese)

13. Wang, X.D.; Wang, X.W.; Su, C.M. REE geochemistry of scheelite and Sm-Nd dating for the houchangchuan scheelite deposit in Gansu. J. Mineral. Petrol. 2010, 30, 64-68. (In Chinese)

14. Brugger, J.; Lahaye, Y.; Costa, S.; Lambert, D.; Bateman, R. Inhomogeneous distribution of REE in scheelite and dynamics of Archaean hydrothermal systems (Mt. Charlotte and Drysdale gold deposits, Western Australia). Contrib. Miner. Petrol. 2000, 139, 251-264. [CrossRef]

15. Schwinn, G.; Markl, G. REE systematics in hydrothermal fluorite. Chem. Geol. 2005, 216, 225-248. [CrossRef]

16. Sylvester, P.J.; Ghaderi, M. Trace element analysis of scheelite by excimer laser ablation-inductively coupled plasma-mass spectrometry (ELA-ICP-MS) using a synthetic silicate glass standard. Chem. Geol. 1997, 141, 49-65. [CrossRef]

17. Gagnon, J.E.; Samson, I.M.; Fryer, B.J.; Williams-Jones, A.E. Compositional heterogeneity in fluorite and the genesis of fluorite deposits: Insights from la ICP MS analysis. Can. Miner. 2003, 41, 365-382. [CrossRef]

18. Ghaderi, M.; Palin, J.M.; Campbell, I.H.; Sylvester, P.J. Rare earth element systematics in scheelite from hydrothermal gold deposits in the Kalgoorlie-Norseman region, Western Australia. Econ. Geol. 1999, 94, 423-437. [CrossRef]

19. Liu, X.F.; Yuan, S.D.; Shuang, Y.; Yuan, Y.B.; Mi, J.R.; Xuan, Y.S. In situ LA-ICP-MS REE analyses of the skarn garnets from the Jinchuantang tin-bismuth deposit in Hunan Province, and their significance. Acta Petrol. Sin. 2014; 30, 163-177. (In Chinese)

20. Liu, B.; Wu, Q.-H.; Li, H.; Evans, N.J.; Wu, J.-H.; Cao, J.-Y.; Jiang, J.-B. Fault-fluid evolution in the Xitian W-Sn ore field (South China): Constraints from scheelite texture and composition. Ore Geol. Rev. 2019, 114, 103140. [CrossRef]

21. Pan, J.Q.; Dai, T.G.; Zhang, D.X.; Li, W.S.; Bayless, R.C.; Gao, J.F. In situ trace elemental analyses of scheelite from the chuankou deposit, South China: Implications for ore genesis. Minerals 2020, 10, 1007. [CrossRef]

22. Song, G.X.; Qin, K.Z.; Li, G.M.; Evans, N.J.; Chen, L. Scheelite elemental and isotopic signatures: Implications for the genesis of skarn-type W-Mo deposits in the Chizhou Area, Anhui Province, Eastern China. Am. Mineral. 2014, 99, 303-317. [CrossRef] 
23. Zhang, Y.; Ma, D.; Gao, J.-F. Origin and evolution of ore-forming fluids in a tungsten mineralization system, Middle Jiangnan orogenic belt, South China: Constraints from in-situ LA-ICP-MS analyses of scheelite. Ore Geol. Rev. 2020, 127, 103806. [CrossRef]

24. Huang, X.P.; Ma, J.F. Metallogenic characteristics and prospecting indicators of the Pantuoshan Tungsten deposit, Inner Mongolia, China. China High Tech Enterp. 2015, 26, 144-145. (In Chinese)

25. Yang, H.Q.; Li, Y.; Li, W.M.; Yang, J.G.; Zhao, G.B.; Wang, X.H. Spatial variation regularity and ore potential of S-type and I-type granites in the Beishan mountain. Acta Geosci. Sin. 2009, 30, 627-633. (In Chinese)

26. Yang, H.Q.; Zhao, G.B.; Li, W.M.; Yang, J.G.; Li, Y.; Wang, X.H.; Jiang, H.B.; Tan, W.J. Formation age and source tracing of the Tungsten-bearing granite belt in the Pantuoshan-Yingzuihongshan area, Inner Mongolia. Geol. Explor. 2010, 46, 407-413. (In Chinese)

27. Zhao, G.B.; Li, W.M.; Yang, H.Q.; Tian, Y.T.; Gao, Y.W.; Du, T.; Quan, S.C. Geological and geochemical characteristics of the Pantuoshan Tungsten-bearing granite mass in Inner Mongolia and its genesis. Geol. Explor. 2011, 47, 828-836. (In Chinese)

28. Zhao, G.B.; Li, W.M.; Yang, H.Q.; Gao, Y.W.; Yang, T.; Jia, J.; Quan, S.C.; Qiao, G.B.; Lei, Y.X. Geological and geochemical characteristics and genesis of tungsten-bearing granite in Pantuo Mountain, Inner Mongolia. Northwest. Geol. 2012, 45, 68-71. (In Chinese)

29. Zhao, G.B.; Li, W.M.; Yang, H.Q.; Gao, Y.W.; Yang, T.; Tian, Y.T.; Quan, S.C.; Qiao, G.B.; Lei, Y.X. Metallogenic characteristics and prospecting indicators of the Pantuoshan Tungsten-bearing granite mass Inner Mongolia, China. Geotecton. Metallog. 2013, 37, 235-241. (In Chinese)

30. Jiang, S.H.; Nie, F.J.; Chen, W.; Liu, Y.; Bai, D.M.; Liu, X.Y.; Zhang, S.H. The determination of the emplacement age of granite in Mingshui, Beishan area, and its implication. Acta Petrol. Mineral. 2003, 22, 107-111. (In Chinese)

31. Nie, F.J.; Jiang, S.H.; Bai, D.M.; Wang, X.L.; Su, X.X.; Li, J.C.; Liu, Y.A.N.; Zhao, S.M. MetallogenicStudies and Ore Prospecting in the Conjunction Area of Inner Mongolia Autonomous Region, Gansu Province and Xinjiang Uygur Autonomous Region (Beishan Mt.), Northwest China; Geological Publishing House: Beijing, China, 2002; pp. 145-220. (In Chinese)

32. Nie, F.J.; Jiang, S.H.; Bai, D.M.; Zhang, Y.; Zhao, Y.M.; Wang, X.L. Type and temporal-spatial distribution of metal deposits in the Beishan Mountains, Inner Mongolia, and its neihboring region. Acta Geol. Sin. 2003, 77, 367-378. (In Chinese)

33. Zuo, G.C.; He, G.Q.; Li, H.C. Plate Tectonics and Metallogenesis Reagularities in Beishan Region; Peking University Press: Beijing, China, 1990; pp. 185-226. (In Chinese)

34. Yang, H.Q. The Studies of Ore Prospecting in Beishan Mineralization Belt, Northwest China (Technical report), 174-Xi'an Center of Geological Survey; Geological Survey of China: Beijing, China, 2008. (In Chinese)

35. Yuan, H.L.; Wu, F.Y.; Gao, S.; Liu, X.M.; Xu, P.; Sun, D.Y. LA-ICPMS zircon U-Pb dating and REE analysis of Cenozoic intrusion from northeastern region of China. China Sci. Bull. 2003, 48, 1511-1520. (in Chinese).

36. Liu, Y.J.; Ma, D.S. Geochemistry of Tungsten; Science Press: Beijing, China, 1987; pp. 1-120. (In Chinese)

37. Taylor, S.R.; Mclennan, S.M. The continental crust: Its composition and evolution, an examination of the geochemical record preserved in sedimentary rocks. J. Geol. 1985, 4, 632-633.

38. Xiong, D.X.; Sun, X.M.; Shi, G.Y.; Wang, S.W.; Gao, J.F.; Xue, T. Trace elements, rare earth elements (REE) and Nd-Sr isotopic compositions in scheelites and their implications for the mineralization in Daping gold mine in Yunnan province, China. Acta Petrol. Sin. 2006, 22, 733-741.

39. Sun, S.S.; Mcdonough, W.F. Chemical and isotopic systematics of oceanic basalts: Implications for mantle composition and processes. Geol. Soc. Lond. Spec. Publ. 1989, 42, 313-345. [CrossRef]

40. Li, X.Y.; Gao, J.F.; Zhang, R.Q.; Lu, J.-J.; Chen, W.H.; Wu, J.W. Origin of the Muguayuan veinlet-disseminated tungsten deposit, South China: Constraints from in-situ trace element analyses of scheelite. Ore Geol. Rev. 2018, 99, 180-194. [CrossRef]

41. Plotinskaya, O.Y.; Baksheev, I.A.; Minervina, E.A. REE distribution in scheelite from the Yubileinoe porphyry gold deposit, South Urals: Evidence from LA-ICP-MS data. Geol. Ore Depos. 2018, 60, 355-364. [CrossRef]

42. Sciuba, M.; Beaudoin, G.; Grzela, D.; Makvandi, S. Trace element composition of scheelite in orogenic gold deposits. Miner. Depos. 2020, 55, 1149-1172. [CrossRef]

43. Štemprok, M.; Pivec, E.; Langrová, A. The petrogenesis of a wolframite-bearing greisen in the Vykmanov granite stock, Western Krušnéhory pluton (Czech Republic). Bull. Geosci. 2005, 80, 163-184.

44. Sun, K.; Chen, B. Trace elements and Sr-Nd isotopes of scheelite: Implications for the W-Cu-Mo polymetallic mineralization of the Shimensi deposit, South China. Am. Mineral. 2017, 102, 1114-1128.

45. Zhu, X.Y.; Wang, J.B.; Wang, Y.L.; Chen, X.Y.; Fu, Q.B.; Tian, Y. The differences of the ore-forming fluid between the vein-type and skarn type tungsten deposits. Acta Petrol. Sin. 2015, 31, 941-953. (In Chinese)

46. Wang, D.; Lu, H.Z.; Bi, X.W. Comparison of characteristics of ore forming fluids between quartz-vein tungsten deposits and porphyry copper deposits asscciated with granitic rocks. Earth Sci. Front. 2011, 18, 121-131. (In Chinese)

47. Zhu, X.Y.; Wang, J.B.; Wang, Y.L.; Chen, X.Y.; Fu, Q.B. Relative closed ore-forming system in the tungsten-bearing quartz vein: A case study of the Yaogangxian deposit, Hunan province. Acta Geol. Sin. 2014, 88, 825-835. (In Chinese)

48. Uspensky, E.; Brugger, J.; Gräser, S. REE geochemistry systematics of scheelite from the Alps using luminescence spectroscopy: From global regularities to facies control. Schweiz. Mineral. und Petrogr. Mitt. 1998, 78, 31-54.

49. Fu, Y.; Sun, X.M.; Xiong, D.X. In-situ determination of rare earth elements in scheelite by laser ablation-inductively coupled plasma-mass spectrometry. Rock Miner. Anal. 2013, 32, 875-882. (In Chinese)

50. Cherniak, D.; Hanchar, J.; Watson, E. Rare-earth diffusion in zircon. Chem. Geol. 1997, 134, 289-301. [CrossRef] 
51. Cherniak, D. REE diffusion in calcite. Earth Planet. Sci. Lett. 1998, 160, 273-287. [CrossRef]

52. Cherniak, D.; Zhang, X.; Wayne, N.; Watson, E. Sr, Y, and REE diffusion in fluorite. Chem. Geol. 2001, 181, 99-111. [CrossRef]

53. Marshall, D. Cathodoluminescence of Geological Materials; Unwin Hyman: Boston, MA, USA, 1988; pp. 1-146.

54. Brugger, J.; Bettiol, A.A.; Costa, S.; Lahaye, Y.; Bateman, R.; Lambert, D.D.; Jamieson, D.N. Mapping REE distri-bution in scheelite using luminescence. Mineral. Mag. 2000, 64, 891-903. [CrossRef]

55. Michard, A.; Albarède, F. The REE content of some hydrothermal fluids. Chem. Geol. 1986, 55, 51-60. [CrossRef]

56. Michard, A. Rare earth element systematics in hydrothermal fluids. Geochim. Cosmochim. Acta 1989, 53, 745-750. [CrossRef]

57. Möller, P.; Dulski, P.; Savascin, Y.; Conrad, M. Rare earth elements, yttrium and Pb isotope ratios in thermal spring and well waters of West Anatolia, Turkey: Ahydrochemical study of their origin. Chem. Geol. 2004, 206, 97-118. [CrossRef]

58. Zhu, D.P.; Li, H.; Algeo, T.J.; Jiang, W.C.; Wang, C. The prograde-to-retrograde evolution of the Huangshaping skarn deposit (Nanling Range, South China). Miner. Depos. 2021, 1-21. [CrossRef] 